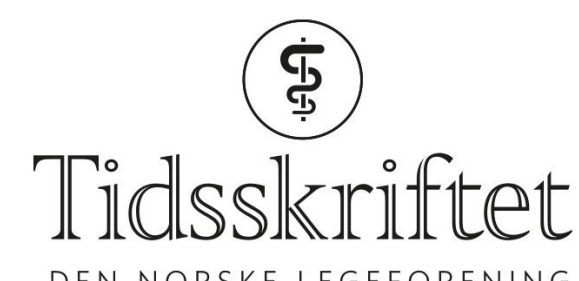

DEN NORSKE LEGEFORENING

\title{
Vorte fra Kløfta
}

LEGELIVET

JAN-ØIVIND HOLM

E-post: holjan@ous-hf.no

Oslo universitetssykehus

Dette diktet ble skrevet i en tid jeg arbeidet med sammenslåingen av hudavdelingene på Ullevål, Rikshospitalet og Olafiaklinikken. Diktets undertone er: Ett legeme, flere helseregioner.

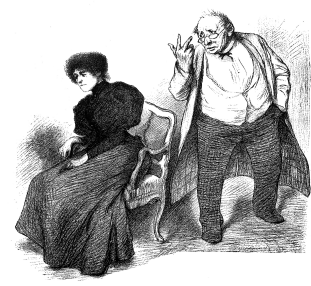

Illustrasjon: maodesign/iStock

Det var en gang en vorte fra Kløfta

som satte seg fast, midt inni grøfta

til madammen så fiin

kledd i liin

fra Lista

Å hjelpe meg, sa doktor'n

Jeg er bekymret for den smitte

De har i skrittet

Hva har De gjort med Deres midte?

Fruen senket blikket

og doktorens hud ble rød

Du skjønner, sa listinnen

Vel, nok om det, sa doktor'n

Nå må vi finne dét hospital

som lurer deres vorte på limpinnen

Helse Øst og Helse $\emptyset \emptyset r$, hmmm

De var fra Kløfta og vorten fra Lista?

Var det slik?

Listinnen brast i skrik.

Det var nok omvendt, doktor! 
Hun gav ham en fik.

Listinnen raste ut av hans kontor

dro rett til apotek

Min vorte den skal blø!

Har dere salve fra Bodø?

Reseptaren skalv på henda

Men De skjønner, frue

Salven er fra Nord

og var De fra Sør?

Kvinnens skrotte dirret

av en harme så fæl

Stormet ut av resepturet

med vorten hakk i hæl

Stakkars vorte!

Den kvelte seg selv rundt halsen

Placebo! Placebo!

La meg bli borte.

Historien ender

Og også vorten sitt liv

$\mathrm{i}$ en grav $\mathrm{i}$ en grøft

i det pjuskete siv

Publisert: 8. april 2019. Tidsskr Nor Legeforen. DOI: 10.4045/tidsskr.19.0123

(C) Tidsskrift for Den norske legeforening 2020. Lastet ned fra tidsskriftet.no 